\title{
階段式魚道の底面に設置した粗石の間隔が オイカワの遡上特性に及ぼす影響
}

\author{
鬼束 幸樹 1 ・秋山 壽一郎 2 ・有須田 朋子 3 ・定地 憲人 4 ・緒方 亮 5 \\ 1 正会員九州工業大学大学院准教授＼cjkstart建設社会工学研究系（广804-8550 北九州市戸畑区仙水町 1-1） \\ E-mail:onitsuka@civil.kyutech.ac.jp \\ 2フェロー会員 九州工業大学大学院教授 建設社会工学研究系（† 804-8550 北九州市戸畑区仙水町 1-1） \\ 3 (株) 清水建設 （干104-8370 東京都中央区京橋 2-16-1） \\ 4 学生会員 九州工業大学大学院 工学府建設社会工学専攻（广804-8550 北九州市戸畑区仙水町 1-1） \\ 5 学生会員 九州工業大学 工学部建設社会工学科（†804-8550 北九州市戸畑区仙水町 1-1）
}

\begin{abstract}
階段式魚道の底面に設置した粗石間隔と魚の遊泳特性との関係はほとんど解明されていない. 本研究で は，階段式魚道の底面に間隔を変化させて粗石を設置し，オイカワの遡上特性の解明を試みた。その結果， オイカワは粗石間隔の増加に伴い，粗石間の空隙を利用して遡上する傾向が顕著になることが判明した. そのため, 粗石間隔の増加に伴い遡上率が増加した。この原因として, 粗石間隔の増加に伴い休䕀場所が 確保されるため, オイカワの疲労が蓄積されにくくなることが挙げられた.
\end{abstract}

Key Words: Opsariichthys platypus, migration rate, pool-and-weir fishway, boulder

\section{1. はじめに}

ダムや堰が河川に設置されると河川水位が縦断方向に 不連続となり，水生生物の河川縦断方向の移動が困難に なる。このような状況はサケ(Oncorhynchus keta)やアユ (Plecoglossus altivelis altivelis)などの通し回遊魚にとっては 種の断絶の危険性があり，魚道の併設が必要不可欠とな る11,2). 我が国における既設魚道の多くは隔壁とプールに よって構成される階段式魚道である3). 階段式魚道の隔 壁には，隔壁幅の2〜3割を占める切欠きが設置されるこ とが多い. 平水時では切欠きのみを水が越流するため, 落下点付近には局所的に高速な流れが発生する.

魚の遊泳速度は，1秒当たりの遊泳距離が体長の約2 4倍程度の維持速度と, 体長の約10倍あるいはそれ以上 の突進速度に大別され4), 前者では疲労の蓄積がなく, 後者ではある. 階段式魚道を遡上する時に魚は突進速度 を使用することがあるため, 疲労の回復が可能な休憩場 所を魚道内に確保する必要がある3). その一つの手法と して，粗石の設置が挙げられる.

金子ら5および高崎ら恀摩川支流の秋川に設置され た粗石付き魚道における魚の遡上調査を行った。 その結 果, 粗石の有無が遡上する魚種および尾数に影響を与え ることを示した。佐合らわは吉井川支流の金剛川に設置
された階段式魚道において，底面の粗石密度を変化させ て魚の遡上調査を行った。 その結果, 粗石密度の増加に 伴い遡上率が増加することを解明した. 魚道を対象とし た研究ではないが，野上ら ${ }^{8}$ は真駒内川における，底生 魚類生息環境の現地実験を行なった結果, 八ナカジカ (Cottus nozawae)の生息密度の小さい場所において，生息 環境を改善するためには粒径を大きくする必要があると 指摘した。桜井ら9は開水路に設置した粗石が流れ場や 魚類の遡上特性に与える影響について検討した。 その結 果，粗石の存在が多様な流速場を形成し，アユなどの遊 泳魚だけでなく，ヨシノボリ(Rhinogobius sp)などの底棲 魚の遡上にとって有益であることを示した. Santos $e t$ $a l .10), 11$ は粒径が0.1mあるいは0.15mの粗石をそれぞれ底面 に設置した魚道で遡上実験を行い，大きな粒径の方が遡 上時間が短縮されることを示した．ただし，魚道の河床 に大量の粗石が堆積し，大幅に流水断面積が減少する場 合は，遡上率が低下する場合もあると青木ら ${ }^{12)}$ は指摘し ている. 以上のように，粗石の有無が遡上特性に影響を 与えることが解明されたが，その原因を解明するには， 魚の挙動および魚道内流況の把握と, 両者の関係を明ら かにしなければならない.

宮園・戸松 ${ }^{13)}$ は粗石を有する魚道内でのイワナ (Salvelinus leucomaenis leucomaenis)の挙動を撮影した。 その 
結果，イワナは粗石前後を遡上経路として選択している ことが解明された．松木ら ${ }^{14}$ は直径が $0.05 \mathrm{~m} の$ 半球を魚 道底面に設置し，流量を変化させてウグイ(Tribolodon hakonensis)の挙動を観察した，その結果，遡上率が高い ケースでは, ウグイが粗石背後の低流速域で休憩してい ることを確認した．鬼束ら ${ }^{15}$ は階段式魚道の底面に直径 $0.1 \mathrm{~m}$ 模擬粗石を最密充填で設置した場合と設置しない 場合の両者でオイカワ(Opsariichthys platypus $)^{16}$ の遊泳特性 を観察した，その結果，底面に模擬粗石を設置すると遊 泳位置が低下寸ることや，オイカワが模擬粗石間を選好 して遊泳することを解明した．以上のように階段式魚道 に粗石を設置した場合の魚の遊泳特性や遡上特性が解明 されつつあるが，粗石間隔と魚の遊泳特性との関係はほ とんじ解明されていない.

本研究は, 階段式魚道の底面に設置する粗石の間隔が オイカワの遡上特性に及ぼす影響を解明したものである.

\section{2. 実験装置および実験条件}

図-1に実験に用いた片側切欠き付階段式魚道の模式 図を示す.下流側から順に第 1，2，3，4 プールとし た. 越流条件は切欠き部のみからとした。プール長 $L=0.7 \mathrm{~m}$, プール幅 $B=0.6 \mathrm{~m}$, 隔壁厚 $\Delta x=0.15 \mathrm{~m}$, 落差 $\Delta y=0.15 \mathrm{~m}$, 切欠き幅 $\Delta z=0.12 \mathrm{~m}$, プール底面から切

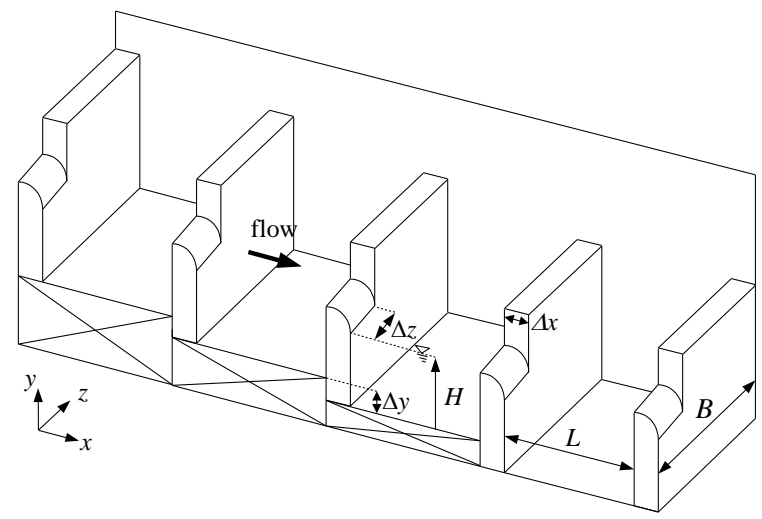

図-1 実験装置の概要

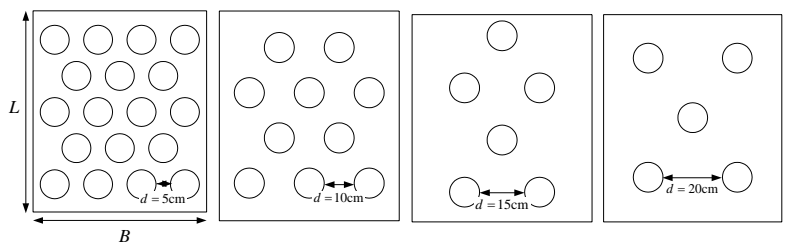

図-2 粗石の配置図

表-1 実験条件

\begin{tabular}{|c|c|c|c|}
\hline \multirow{2}{*}{$Q(1 / \mathrm{s})$} & $\begin{array}{c}\text { diameter of } \\
\text { boulders } D(\mathrm{~cm})\end{array}$ & $\begin{array}{c}\text { interval of } \\
\text { boulders } d(\mathrm{~cm})\end{array}$ & case name \\
\hline \multirow{3}{*}{7} & \multirow{3}{*}{10} & 5 & $\mathrm{I} 5$ \\
\cline { 3 - 4 } & \multirow{2}{*}{10} & 10 & $\mathrm{I} 10$ \\
\cline { 3 - 4 } & & 15 & $\mathrm{I} 15$ \\
\cline { 3 - 4 } & & 20 & $\mathrm{I} 20$ \\
\hline
\end{tabular}
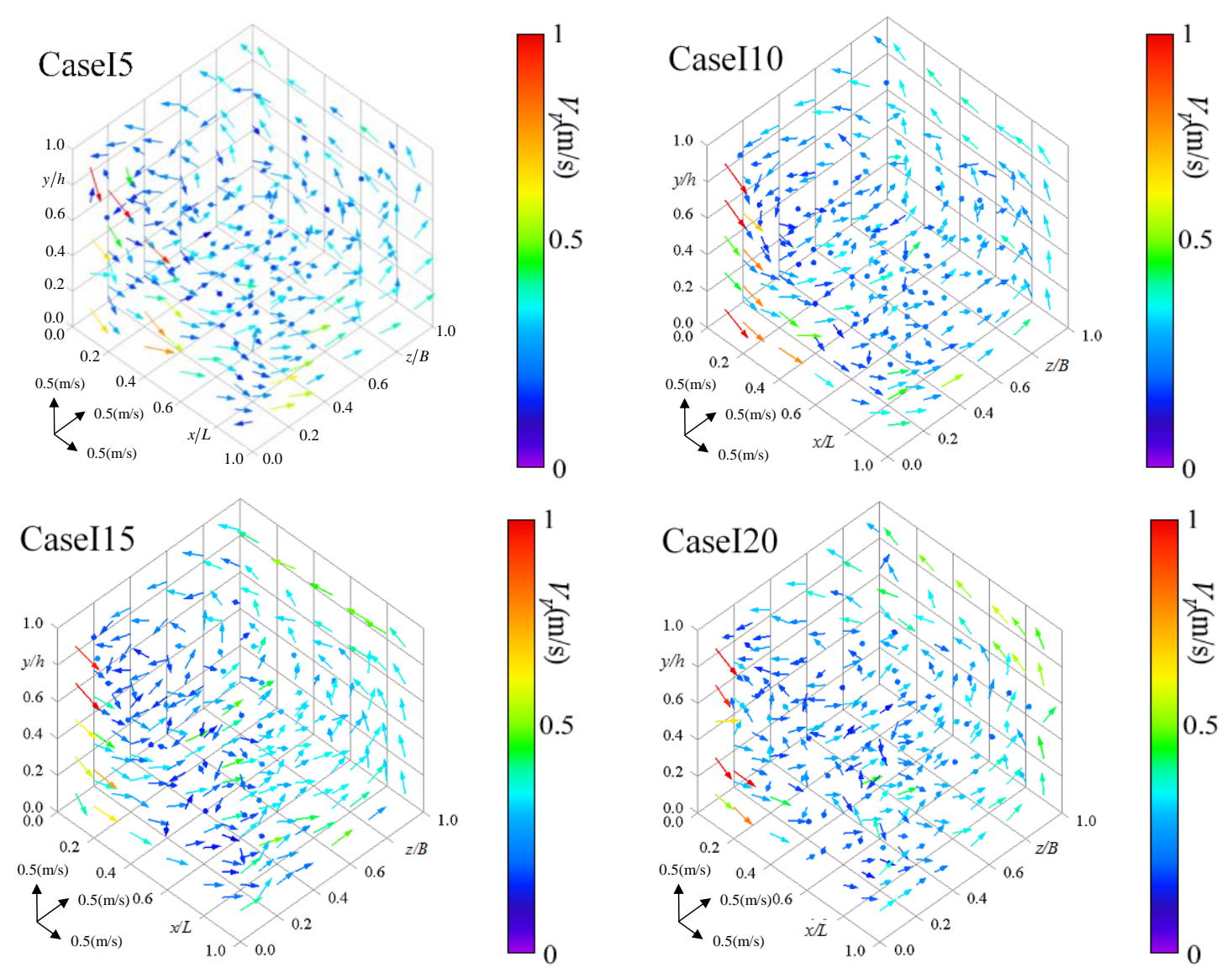

図-3 3 次元合成流速ベクトル 


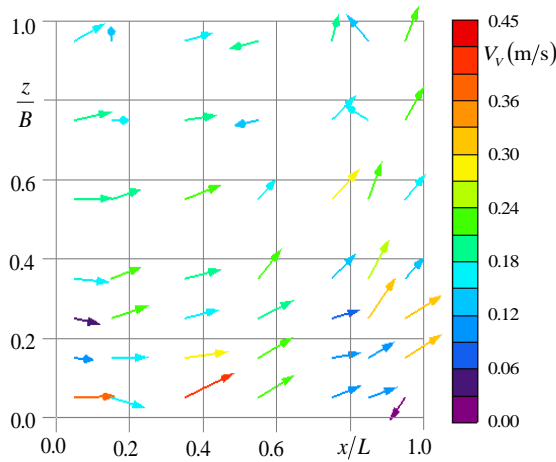

(a) Casel5

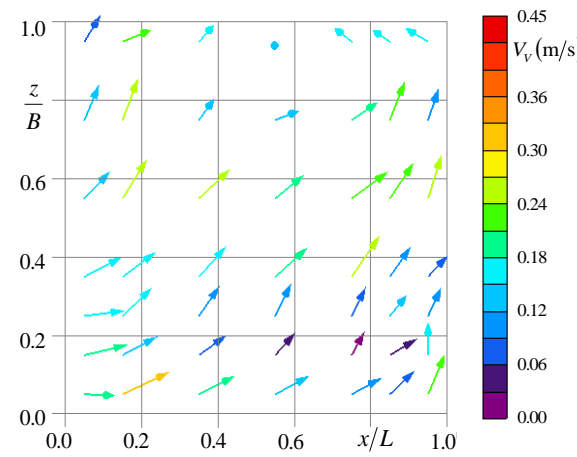

(c) CaseI15

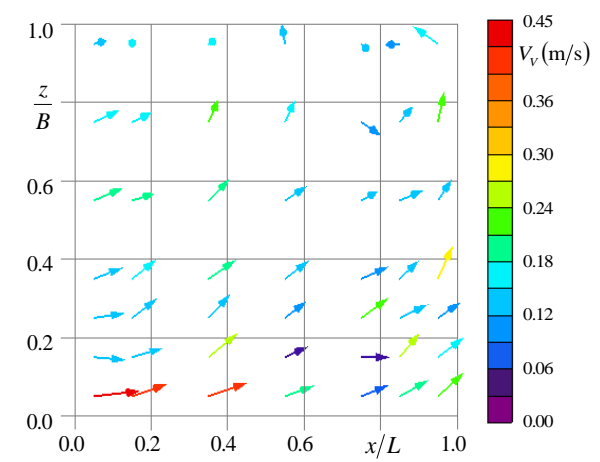

(b) Casel10

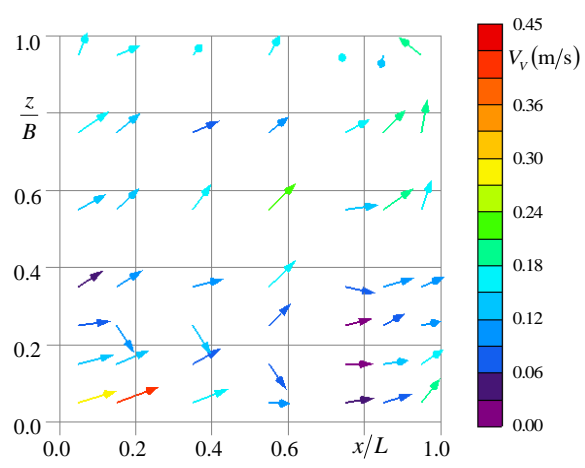

(d) Casel20

図-4 $y / h=0.1$ における水平断面内の流速散布図

欠き下端までの高さ $H=0.3 \mathrm{~m}$, 粗石頂部を底面とし た時の水深 $h=0.2 \mathrm{~m}$ とした. 流下方向に $x$ 軸, 鉛直上 向きに $y$ 軸，横断方向に $z$ 軸をとった．魚道の素材は グレーに塗装した木製であるが，左岸側壁は撮影の ために透明なアクリル板で作成した。

粗石形状として，自然石に近い球形を採用した ${ }^{17}$. 粗石を配置する場所は第 2 プールの底面のみとした. 図 -2に示すように, 粗石の配置として最密充填構造を基 本とし, 徐々に粗石間隔を増加させた。表-1に実験条 件を示す. 流量 $Q$ を7(1/s) で一定とし, 直径 $D=10 \mathrm{~cm}$ の粗石間隔 $d$ を $5,10,15$ および $20 \mathrm{~cm}$ の 4 通りに変 化させた. なお, 粗石の最上部を $y=0$ とした.

供試魚にはオイカワを選択した. オイカワはアユ などの同じ体長の魚に比べて遊泳力が低い. そのた め, オイカワが遡上可能な魚道を設計することで, その他多数の魚種にも適用することができる．第 370 一ルに平均体長 $\overline{B_{L}}=70 \mathrm{~mm}$ のオイカワを $N=20$ 尾放流 した. なお，使用したオイカワの最小および最大体 長はそれぞれ 68mm，74mm であり，予備実験で突進 速度に大きな違いはなかった。これより，才イカワ の体長の違いによる遊泳挙動への影響は小さいと考 えられる. 3 分程度馴致した後, 側壁および魚道上部 に設置した 2 台のビデオカメラで $30 \mathrm{fps}, 20$ 分間の撮 影を行った. 撮影後, オイカワの遊泳位置を $10 \mathrm{~s}$ ごと に解析すると共に, 遡上数をカウントした.

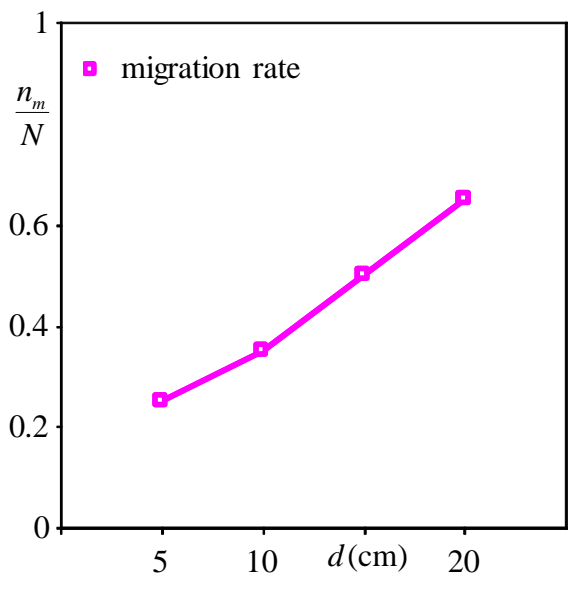

図-5 オイカワの遡上率

$x, y, z$ 軸方向にそれぞれ 7, 5, 7 点のメッシュ で構成される合計 245 点において，3 次元電磁流速計 を用いて流速 3 成分を $0.05 \mathrm{~s}$ 間隔で $25.6 \mathrm{~s}$ 計測した。計 測後, $x, y, z$ 軸方向の時間平均流速 $U, V, W$ および 3 次元合成流速 $V_{V}=\sqrt{U^{2}+V^{2}+W^{2}}$ を算出した.

\section{3. 実験結果および考察}

\section{（1）プール内の水理特性}

図-3 に第 2 プール内における 3 次元合成流速 $V_{V}$ を, 全 ケースについてベクトル表示した. 全ケースにおいて, 上流側切欠き $(0 \leq z / B \leq 0.2)$ からの落下流がプール底面付 近まで潜りこみ, 下流側隔壁 $(x / L=1.0)$ に衝突した後に 


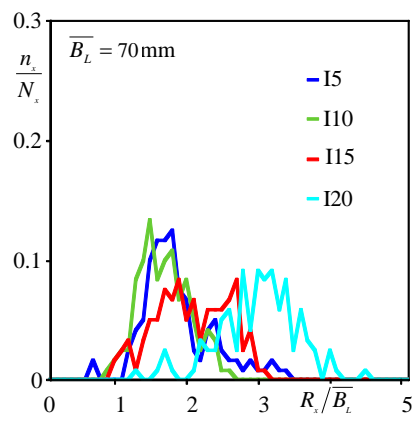

(a) $x$ 軸方向の魚群半径

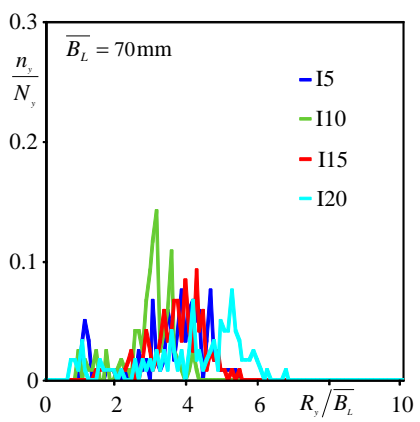

(b) $y$ 軸方向の魚群半径

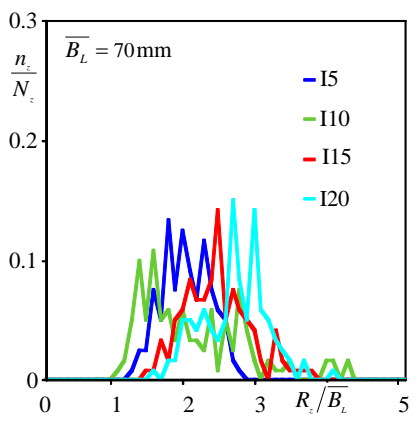

(c) $z$ 軸方向の魚群半径

図-6 $x, y$ およびz軸方向それぞれの瞬間遊泳位置における魚群半径の頻度分布

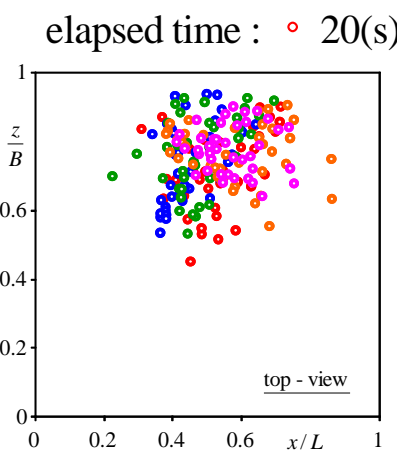

(a) Casel5

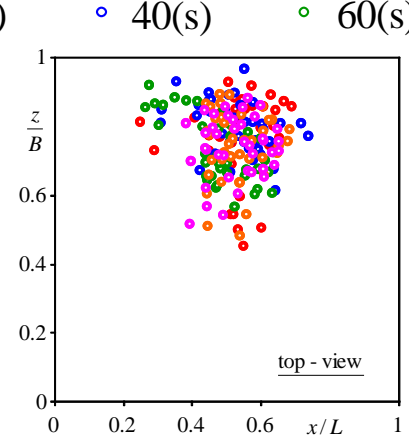

(b) CaseI10

- $80(\mathrm{~s}) \quad 100(\mathrm{~s})$

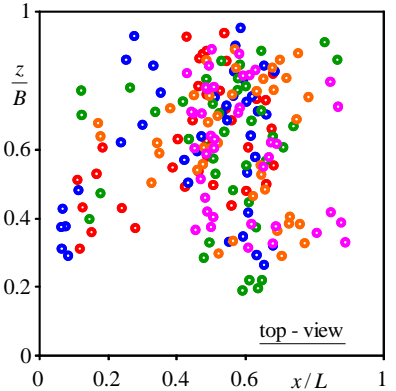

(c) Casel15

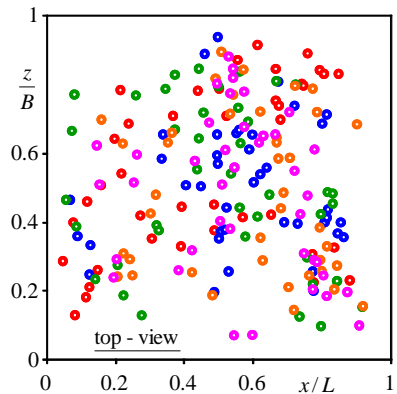

(d) Casel20

図-7 水平断面 $(x-z)$ における瞬間遊泳位置

左岸側水面付近に上昇し，循環流を形成していることが 確認される．そのため，今回の実験条件の範囲内におい ては，粗石間隔 $d$ を変化させてもプール内の流況は巨 視的には類似しているといえる.

図-4 に第 2 プール内の粗石頂部 $(y=0)$ に最も近い流速 計測位置 $y / h=0.1$ における水平断面 $(x-z)$ の 3 次元合成 流速 $V_{V}$ を, 全ケースについて散布図で表示した。いず れのケースにおいても, 右岸側壁 $(z / B=0)$ 付近の比較的 上流領域 $(0 \leq x / L \leq 0.5)$ において流速が速くなっている.

これは，上流側切欠き $(0 \leq z / B \leq 0.2)$ からの落下流の影響 によるものである. 図-4の 4 つのケースを比べると， $0 \leq Z / B \leq 0.2,0 \leq x / L \leq 1.0$ の範囲では粗石間隔 $d$ が広くな るにつれて流速が遅くなっているのが分かる．また，プ 一ル全体で見ると, 粗石間隔 $d$ が一番狭いケース 5 よ り $d$ が一番広いケース 120 の方が流速が遅くなっている のが分かる. これは, 粗石間隔 $d$ の増加に伴い, 粗石頂 部 $(y=0)$ 以下の空隙が増加し, 落下流がより広い範 囲に流れ込むことで粗石頂部付近での流速が遅くなって いると考えられる. なお, 粗石頂部 $(y=0)$ 以下では, 粗 石間隔 $d$ の変化に伴い, 流速場が顕著に変化している と推定される ${ }^{18)}$.

\section{(2) オイカワの遡上率}

遡上率を次式のように定義した。

$$
\text { 遡上率 }=\frac{\text { 遡上に成功した尾数 } n_{m}}{\text { 実験に用いた尾数 } N(=20)}
$$

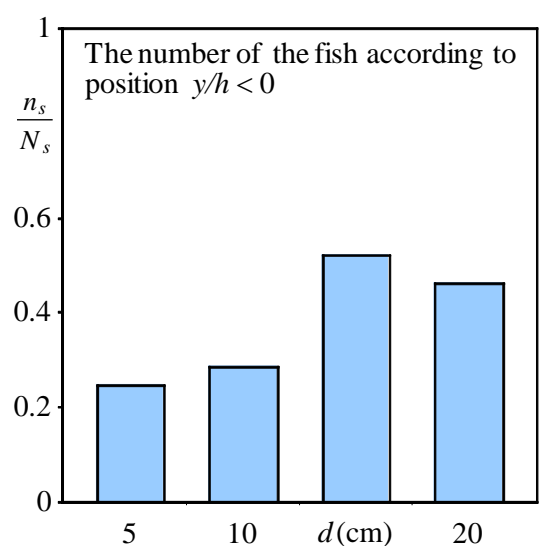

図-8 粗石間隔と $y$ 軸方向 $(y / h<0)$ の遊泳位置の関係

図-5 に粗石間隔 $d$ とオイカワの遡上率 $n_{m} / N$ との関係 を示す. 粗石間隔 $d$ の増加に伴い遡上率 $n_{m} / N$ が増加 している. 図-3より全ケースにおいて巨視的には流況 が類似していることが判明した。 そのため, 遡上率 の変化は粗石間隔の変化によって発生していると推 定される.この詳細な原因を解明するには, 粗石間隔 $d$ の増加に伴うオイカワの挙動の変化を解明しなけれ ばならない.

\section{(3) 粗石間隔の変化によるプール内の遊泳特性の変化}

図-6に $x, y$ および $z$ 軸方向の魚群半径を平均体長 $\overline{B_{L}}$ で除した值 $R_{x} / \overline{B_{L}}, R_{y} / \overline{B_{L}}$ および $R_{z} / \overline{B_{L}}$ の頻度 分布を示す. 若干例外があるものの, 粗石間隔 $d$ の増 

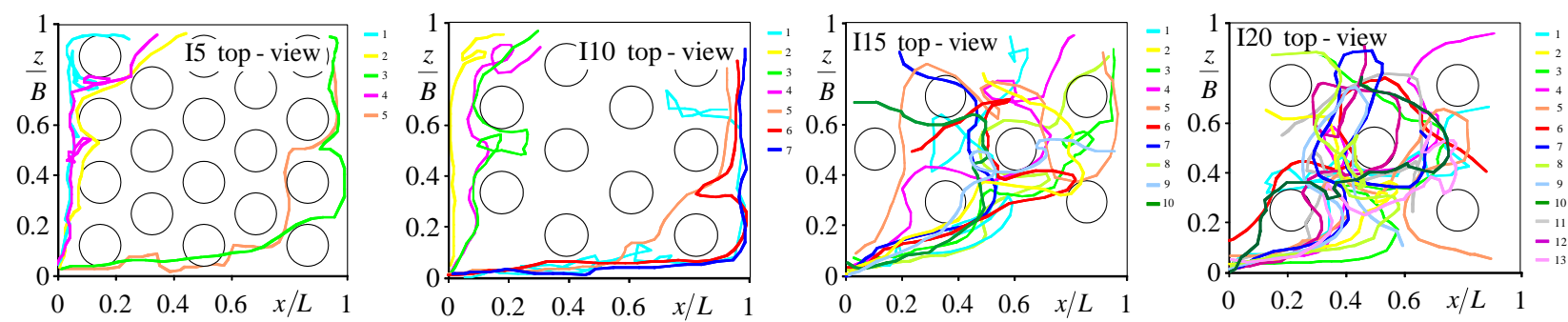

図-9 水平断面 $(x-z)$ における遡上経路

加に伴い各魚群半径のピーク值が増加する傾向が観察さ れる。これは, 粗石間隔 $d$ が増加すると, オイカワが 散乱して遊泳することを示している.

図-7に各ケースにおいて. 実験開始後 100s 間のオイ カワ $(\mathrm{N}=20$ 尾)の水平遊泳位置を $20 \mathrm{~s}$ ごとに色分けして示 した. 図-7 は水平断面で観察した時にプール内のどの 場所を遊泳しているかを解析しており, $y$ 方向の遊泳位 置の範囲は $0 \leq y / h \leq 1$ である. 粗石間隔 $d$ が比較的㹨い ケース 15 および 110 の場合は，右岸傊壁 $(z / B=0)$ 付近を 避けて遊泳している. 一方, 粗石間隔 $d$ が比較的広い ケース I15 および 120 の場合は，プール内を散乱して遊 泳している.

図-6 および図-7 より粗石間隔 $d$ が狭い場合は上流側 切欠きから離れた左岸側を密集して遊泳するが，粗石間 隔 $d$ が増加するとプール全体を散乱して遊泳すること が明らかとなった。 これは図-4から分かるように，粗石 間隔 $d$ の増加に伴い, 高速領域が存在する左岸側に位置 する粗石頂部付近の流速が遅くなることで, オイカワが 遊泳できる範囲が広がった結果, 散乱したのだと考えら れる．また，オイカワは流れの上流方向に泳ぎたがる正 の向流性を有している. そのため, 遊泳位置が上流側切 久きから離れると, 落下流を見つけにくくなるため, 遡 上の機会が減少すると推定される.

\section{(4) 粗石間の利用状況}

オイカワは粗石頂部 $(y=0)$ より上部領域だけでなく, 下部領域，すなわち粗石間も遊泳していた。 図-8に才 イカワの遊泳位置が $y / h<0$ となる存在確率 $n_{s} / N_{s}$ を示 した. 粗石間隔 $d$ の増加に伴い, 存在確率 $n_{s} / N_{s}$ が増 加する傾向を示している. この原因は主として次の $2 つ$ が推定される. まず, 粗石間隔 $d$ が増加すると, 平均 体長 $\overline{B_{L}}$ が $70 \mathrm{~mm}$ のオイカワが物理的に粗石間に入りや すくなることが挙げられる。一方，図-4 で観察された ように, 底面付近では粗石間隔 $d$ の増加に伴い流速が 減少する. オイカワに限らず魚の筋肉は普通筋と血合筋 によって構成されるが, 緊急時以外は疲労の蓄積が生じ る普通筋を使いたがらない，通常は疲労の蓄積が生じな い血合筋のみを使用寸る維持速度以下で遊泳したがる. 維持速度は $1 \mathrm{~s}$ 当たり体長の 2〜4倍の距離に相当する.

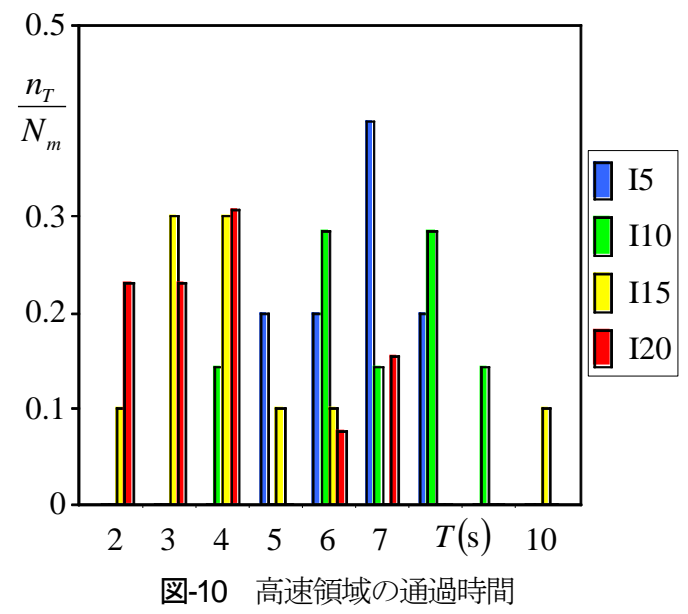

したがって, 粗石間隔 $d$ の増加に伴い, オイカワは維 持速度以下で遊泳できる粗石間を利用するようになった と考えられる。

\section{(5) 粗石間隔の変化による遡上経路の変化}

図-9 に各ケースにおける遡上前の $20 \mathrm{~s}$ 間における水平 断面 $(x-z)$ の経路を全て示した. なお，オイカワが遡上し た順番に番号を付け，色分けしている． $y$ 方向の遊泳位 置については，粗石間を利用したオイカワが存在したの で, $0 \leq y / h \leq 1$ である. 粗石間隔 $d$ が比較的狭いケース I5 および 110 の場合は，オイカワはプール壁面に沿って 遡上している. 一方, 粗石間隔 $d$ が比較的広いケース I15 および 120 の場合は, 粗石の空隙を利用して遡上し ている. 宮園・戸松ら ${ }^{13}$ は，イワナが粗石前後を遡上経 路として選択していることを示した. 本実験結果も宮 園・戸松ら ${ }^{12}$ の結果と類似した結果となった.

遡上経路が異なると, 遡上経路上の流速が異なるため, オイカワが接する流速が異なる. オイカワは上流側切欠 きに接近するに従い，落下流の影響を受けるようになる. ここで, $0 \leq x / L \leq 0.5,0 \leq y / h \leq 1,0 \leq z / B \leq 0.12$ の領域を 高速領域と定義する. 図-10 にオイカワが遡上する際に, 高速領域を通過するのに要した時間 $T(\mathrm{~s})$ の頻度分布を 示した. 各ケースで, 通過時間 $T$ ごとのオイカワの尾 数を $n_{T}$, 遡上したオイカワの尾数を $N_{m}$ とした. ケー ス I5, I10 の粗石間隔 $d$ が狭い場合は通過時間 $T=6 \sim$ 8(s)の頻度が高くなっている. 一方，ケース $\mathrm{I} 15 ， 120$ の 粗石間隔dが広い場合はケース I15，120 よりも短い通 
過時間 $T=2 \sim 4(\mathrm{~s})$ の頻度が高くなっている. これは, 図8 で観察されたように, 粗石間隔 $d$ の増加に伴い, 遡上 前に粗石の空隙を多く利用することが原因である. 粗石 間隔 $d$ の増加に伴い低流速な粗石の空隙を利用するこ とで, 疲労の蓄積が低減され, 遡上率が高くなったと考 えられる.

\section{4. おわりに}

本研究は，階段式魚道の底面に設置された粗石の間隔 がオイカワの遡上特性に及ぼす影響を解明したものであ る. 本実験条件内で得られた知見は以下の通りである.

粗石間隔の増加に伴い，粗石頂部以下の領域では空隙 が増加する. この領域は粗石頂部より上方の領域より低 流速であるため, オイカワは休憩場所として利用する. また，粗石間隔の増加に伴い，遡上前に低流速な粗石間 を利用する頻度が増加するため, 高速流に接する時間が 減少する. その結果，粗石間隔の増加に伴い疲労の蓄積 が低減されるために遡上率が増加したと考えられる.

謝辞：本研究を実施するに当たり，科学研究費補助 金基盤研究(C)26420500 (代表 : 鬼束幸樹)の援助を受 けた.

\section{参考文献}

1) 国土交通省水管理・国土保全局HP : 魚がのぼりやすい川 づくりの手引き, pp.9-146,2005.

2) (財) ダム水源地環境整備センタ一編 : 最新魚道の設計, 信山社サイテック, pp.5-326, 1998.

3) 中村俊六 : 魚道のはなし, 山海堂, pp.42-49, 1995.

4) Sanz-Ronda, F.J., Ruiz-Legazpi, J., Bravo-Córdoba, F.J., Makrakis, S. and Castro-Santos, T.: Sprinting performance of two Iberian fish: Luciobarbus bocagei and Pseudochondrostoma duriense in an open channel flume, Ecological Engineering, Vol.83, pp.61-70, 2015.

5) 金子義明, 和泉清, 土屋十图, 大竹義男 : 秋川における 魚道の水理特性と遡上効果, 水工学論文集, 第 42 巻, pp.265-270, 1997.
6) 高崎忠勝, 土屋十图，大竹義男 : 秋川における複合型魚 道の効果，河川技術に関する論文集，第 5 巻，pp.165-170, 1999.

7) 佐合純造，本多卓志，大木孝志，田中直也：大田原堰魚 道におけるアユの遡上実験報告，水工学論文集，第 42 巻, pp.493-498, 1998.

8）野上毅, 渡邊康玄, 中津川誠, 土屋進, 岩瀬春夫, 渡辺 恵三，加村邦茂 : 真駒内川における底生魚種生息環境の 改善についての現地実験，河川技術論文集，Vol.7， pp.309-314, 2001.

9) 桜井力, 柏井条介, 佐々木國隆, 岡㠃克美, 進藤邦雄, 岡本俊策 : コンクリートプロックを用いた粗石式魚道の 水理および遡上特性, 水工学論文集, 第 44 巻, pp.1197$1202,2000$.

10) Santos, J.M., Branco, P., Silva, A.T., Katopodis, C., Pinheiro, A., Viseu, T. and Ferreira, T.: Effect of two flow regimes on the upstream movements of the Iberian barbel (Luciobarbus bocagei) in an experimental pool-type fishway, Journal of Applied Ichthyology, Vol.29, pp.425-430, 2013.

11) Santos, J.M., Branco, P., Katopodis, C., Ferreira, T. and Pinheiro, A. T.: Retrofitting pool-and-weir fishways to improve passage performance of benthic fishes, Ecological Engineering, Vol.73, pp.335-344, 2014.

12）青木宗之, 向井健朗, 㐘池裕太, 松木越: 階段式魚道の プール内における礫の堆積が魚類の行動に及ぼす影響に つい，土木学会論文集 B1(水工学), Vol.71, No.4, I_1099I_1104, 2015.

13）宮園正敏, 戸松修: 斜路式魚道における粗石の配置につ いて, 砂防学会誌, Vol.56,No.1,pp.3-12,2003.

14) 松木越, 青木宗之, 㐘池裕太, 福井吉孝: 全断面粗石付 魚道の機能増進および修復について, 土木学会論文集 B1(水工学), Vol.71,No.4,I_1105-I_1110,2015.

15）鬼束幸樹，秋山壽一郎，宍戸陽，高松周平，角田裕香， 有須田朋子 : 階段式魚道のプール底面に設置した粗石が 魚の遡上特性に及ぼす影響, 土木学会論文集B1 (水工学), Vol.72,No.4,I_1135-I_1140,2016.

16) 中坊徹次 : 日本産魚類検索, 東海大学出版会, 2013.

17）宮園正敏, 高氏つぐみ, 戸松修: 粗石周辺の水理特性と 渓流魚の遊泳行動, 砂防学会誌, Vol.57, No.5, pp.15-24, 2005.

18) Nezu, I. and Nakagawa, H.: Turbulence in Open-Channel Flows, IAHRMonograph, Balkema, Rotterdam, 1993.

(2016.9.30 受付)

\title{
EFFECTS OF BOULDER INTERVAL OVER POOL BED IN POOL-AND-WEIR FISHWAY ON MIGRATION RATE OF OPSARIICHTHYS PLATYPUS
}

\author{
Kouki ONITSUKA, Juichiro AKIYAMA, Tomoko ARISUDA, Kento JOJI \\ and Ryo OGATA
}

It is important to keep suitable area by boulder in pool-and-weir fishway to make the migration rates of fish high. In this study, migrating behaviors of Oikawa (Opsariichthys platypus) in pool-and-weir fishway were compared with interval of boulders placed on the bottom of pool-and-weir fishway changed. Migration behaviors of Oikawa were obtained with the aid of two sets of digital video cameras. It was found that Oikawa migrates remarkably uses space between boulders with an increase of interval of boulders. It is because the velocity of this space is low as compared with the higher layer. As the result, the migration rate of Oikawa increases with an increase of the boulder interval. 